\title{
陽極酸化時金属塩添加の影響および二重 電解皮膜について
}

\author{
吉村長蔵*・野口駿雄*
}

\author{
Effects of Addition of Metallic Salts on Single and Double \\ Anodizing and Anodized Films \\ Studies on the Finishing of Aluminum in Alkaline Media (Part 5)
}

Chozo YOSHIMURA and Hayao NOGUCHI

Investigations were made on the effects of the addition of various metallic salts on anodizing of aluminum in sodium hydroxide and alkaline-acid double electrolytic oxidation, and the properties of the films produced were also discussed.

An anodized film (about $7 \mu$ by microscopy) was prepared in $\mathrm{NaOH}\left(5 \times 10^{-2} \mathrm{~mol}\right)$ containing metallic salts of $5 \times 10^{-3} \mathrm{~mol}$ by electrolysis for $30 \mathrm{~min}$. under D.C. current density of $1 \mathrm{amp} / \mathrm{dm}^{2}$.

The result showed that the film had a higher corrosion resistance to acid $\left(10 \% \mathrm{H}_{2} \mathrm{SO}_{4}\right)$ and base $(10 \% \mathrm{NaOH})$ as compared with the anodized film of nearly the same thickness produced in $\mathrm{H}_{2} \mathrm{SO}_{4}$, but its scratch hardness (by Martens' hardness tester under a load of $50 \mathrm{~g}$ ) was not so high.

Then, the film produced in the above bath containing zincate had very higher corrosion resistance and hardness (15.0) as compared with the film produced in $\mathrm{NaOH}$ bath of the same concentration containing no metallic salts.

In double anodizing process, an anodized film, which had been prepared in the proposed alkaline bath and then electrolyzed in sulfuric acid by D.C. current density of $1 \mathrm{amp} / \mathrm{dm}^{2}$ for $30 \mathrm{~min}$., had a great thickness (about $7 \mu$ or more) as expected and a higher corrosion resistance as compared with the single anodized film.

\section{1. 緒言}

水酸化アルカリ単独浴中または有機酸塩添加浴中で得 られた皮膜は, 硫酸陽極酸化膜と比較して, 一般に, 耐 アルカリ性にはすぐれているが，カタサは劣る。

アルカリ性浴中に金属塩を添加して陽極酸化を行なら ことにより, 皮膜中に添加金属の酸化物などが沈着し,カ タサなどの物性を改良することができると考えられる。

したがって, 水酸化アルカリに可溶性の金属塩を添加 して陽極酸化を行ない, 得られた皮膜の物性を硫酸陽極 酸化膜と比較した。

†アルミニウムのアルカリ性浴処理法の研究(第 5 報) 前報（第 4 報）：金属表面技術，22，226（1971）

* 近畿大学理工学部 (大阪府東大阪市小若江 321) Department of Applied Chemistry. Faculty of Science and Engineering. Kinki University
また，さきに述べたごとく，硫酸陽極酸化膜とアルカ リ性浴中にて得られた皮膜（以下，アルカリ性電解皮膜 と略称する）とは耐アルカリ性, カタサなどの物性が相 反し，両者は一長一短を有する。

ゆえに, この両者の相乗効果を得る目的で, アルカリ 性浴中で陽極酸化後, さらに硫酸浴中で陽極酸化を行な らか, または逆に, 硫酸浴中で陽極酸化後, アルカリ浴 中で陽極酸化を行なった結果, アルカリ性電解皮膜と硫 酸アルマイトとが二重に生成することを認めた（この二 重に生成した皮膜を，以下，二重電解皮膜と略称する）。 したがって，この二重電解皮膜についても同様に，硫 酸アルマイト, アルカリ性電解皮膜と比較検討した。

\section{2. 実 験 方 法}

\section{2-1 電解浴組成}

アルカリ性浴には， $0.05 \mathrm{M} / l$ (以下 $\mathrm{M}$ と略す）の水酸 化ナトリウム溶液を基液に用い, $5 \times 10^{-3} \mathrm{M}$ の 硫酸严 
鉛,メタアルミン酸ナトリウム, 硫酸カドミウム, 硝酸 ビスマス,タングステン酸ナトリウム, モリブデン酸ナ トリウム, バナシン酸ナトリウム, 硫酸ベリリウムなど の金属塩をそれぞれ添加し，液量を $1 l$ として電解を 行なった。

ただし，ビスマスおよびカドミウムを添加した場 合 は, 加水分解を防止するために, $0.2 \mathrm{M}$ の酒石酸を添加 したため, 水酸化ナトリウムの濃度を $0.52 \mathrm{M}$ とし, 亜 鉛添加浴では0.2M とした。

二重電解皮膜を生成させる場合の硫酸の濃度は, $15 \%$ (W/vol) とした。

\section{2-2 試験片および対橧}

$99.50 \%$ 純アルミニウム $(5 \times 10 \times 0.03 \mathrm{~cm})$ を用い, 同面積のステンレスを対極とした。また，硫酸浴中で陽 極酸化する場合は，同じ面積の鉛を陰極とした。

\section{2-3 它解条件}

電流密度扎よび電解時間は, $1 \mathrm{~A} / \mathrm{dm}^{2}$, 30min を基準 としたが，二重電解皮膜生成法の場合，適宜变えた。浴 温度は $10^{\circ} \mathrm{C}$ と，カクハンはマグネティックスタラー により行なった。

\section{2-4 封孔処理法}

沸騰水に $30 \mathrm{~min}$ 間浸セキおよび赤血塩を主成分とす る常温封孔液 ${ }^{1)}\left(25^{\circ} \mathrm{C}\right)$ に, $10 \mathrm{~min}$ 間浸セキして封孔処 理を行なった。

\section{2-5 皮膜検查法}

2-5-1 膜厚およびカタサ測定法
膜厚はパーマスコープにより測定し，カタサはマルテ ンス式ヒッカキカタサ試験器により，ヒッカキカタサを 测定した。（ただし，荷重50g）

\section{2-5-2 耐アルカリ性試験}

JIS 8601 に準じて，10\% 水酸化ナトリウムにより耐 アルカリ性試験を行なった。

\section{2-5-3 耐酸性試験}

$50^{\circ} \mathrm{C}$ に加温した $10 \%$ (vol/vol) 硫酸または濃りン 酸 $35 \mathrm{~m} l$, 無水クロム酸 $20 \mathrm{~g}$ を水に溶解して $1 l$ とした 酸化皮膜ハク離液 ${ }^{2}$ を $95^{\circ} \mathrm{C}$ に保ち, 試験片を浸セキし, テスターにより通電性を確認しながら，皮膜が完全に溶 解するまでの時間を測定した。

\section{2-6 電流一電圧曲線測定法}

陽極に $1 \mathrm{dm}^{2}$ のアルミニウム試験片を用い, 同面積の ステンレスを対極として，0～30V まで種々電圧を変化 させて直流を通じ，そのおのおのの電流值を測定し，電 流一電圧曲線を求めた。また，電流および電圧一時間曲 線を求めた。電流一電圧曲線の場合，０３0V まで電圧 を種々変えたときの電流を測定したが，この範囲内での おのおのの電圧に拈ける電流値は, 約 $10 \mathrm{~V}$ まで, 約 $1 \mathrm{~min}$ で一定値に達したが, 電圧が増加するに従って, 電流值 の安定する時間が長くなり，測定が困難であった。すな わち，皮膜の生成により電流值が低下していると思われ るので,すべて $1 \mathrm{~min}$ 後の電流值を測定した。また，電 流一時間曲線および電圧一時間曲線については, 電解開 始後，30minまで，各時間における電流值および電圧を

等1衣 カタサ・耐アルカリ性および耐酸性試験結果比較表

\begin{tabular}{|c|c|c|c|c|c|c|c|c|c|}
\hline 試験片 & 未 & 封 & 孔 & 沸 & 滕 水 封 & 孔 & 常 & 封 & 孔 \\
\hline $\begin{array}{l}\text { 皮膜 } \\
\text { 生成浴 }\end{array}$ & $\begin{array}{l}\text { ヒッカキ } \\
\text { カタサ }\end{array}$ & $\begin{array}{l}\text { 耐アルカリ } \\
\text { 性 ( } \mathbf{s})\end{array}$ & $\begin{array}{c}\text { 耐 酸 性 } \\
(\mathrm{min})\end{array}$ & $\begin{array}{l}\text { ヒッカキ } \\
\text { カタサ }\end{array}$ & $\begin{array}{l}\text { 耐アルカリ } \\
\text { 性 ( } \mathbf{s})\end{array}$ & $\begin{array}{c}\text { 耐 酸 性 } \\
\text { (min) }\end{array}$ & $\begin{array}{c}\text { ヒッカキ } \\
\text { カタ サ }\end{array}$ & $\begin{array}{l}\text { 耐アルカリ } \\
\text { 性 ( } \mathrm{s})\end{array}$ & $\begin{array}{c}\text { 耐 酸 性 } \\
(\mathrm{min})\end{array}$ \\
\hline $\mathrm{H}_{2} \mathrm{SO}_{4}$ & 15.9 & 15 & 1.5 & 16.2 & 30 & 6.0 & 16.8 & 45 & 5.0 \\
\hline $\mathrm{HaOH}$ & 11.0 & 35 & 2.5 & 11.0 & 180 & 12.0 & 12.3 & 320 & 14.0 \\
\hline $\mathrm{Zn}$ 添加浴 & 14.6 & 65 & 4.0 & 15.0 & 320 & 70.0 & 15.4 & 305 & 70.0 \\
\hline $\mathrm{Cd} "$ & 13.6 & 50 & 3.0 & 13.9 & 210 & 15.0 & 14.6 & 240 & 16.0 \\
\hline $\mathrm{Al} "$ & 11.0 & 40 & 3.5 & 11.7 & 250 & 13.5 & 12.5 & 260 & 8.0 \\
\hline $\mathrm{Bi} \quad$ & 13.6 & 35 & 2.5 & 13.6 & 280 & 15.0 & 14.6 & 285 & 12.5 \\
\hline W " & 13.5 & 45 & 2.0 & 13. 2 & 130 & 12.5 & 13.9 & 120 & 11.0 \\
\hline Mo " & 11.6 & 65 & 2.5 & 11.3 & 280 & 10.0 & 12.3 & 210 & 7.0 \\
\hline V & 14.2 & 50 & 2.5 & 14.2 & 220 & 35.0 & 14.6 & 280 & 30.0 \\
\hline $\mathrm{Be} "$ & 13.9 & 65 & 2.0 & 14.2 & 130 & 9.0 & 14.6 & 180 & 6.5 \\
\hline 素 材 & 7.1 & - & 一 & 7.1 & - & - & 7.1 & - & - \\
\hline
\end{tabular}


測定した。

\section{3. 実 験 結 果}

\section{3-1 金属塩添加による効果}

金属塩を添加したアルカリ性浴中で，初期電流密度を 約 $1.2 \mathrm{~A} / \mathrm{dm}^{2}$ として $30 \mathrm{~min}$ 間陽極酸化を行ならこと により，いずれの場合も， $7 \pm 1 \mu$ の皮膜を生成した。 また，この皮膜は，硫酸陽極酸化皮膜に類似した無色透 明の皮膜であった。したがって, 種々の金属塩を添加し た水酸化ナトリウムアルカリ性浴中で得られたそれぞれ の試片について，沸騰水封孔および常温封孔処理を行な い，封孔処理法による差異を検討するとともに，未封孔 の試片と，ヒッカキカタサ, 耐アルカリ性打よび耐酸性 試験を行ない，同じ膜厚の硫酸陽極酸化皮膜および金属 塩を添加していない水酸化ナトリウム単独浴中で生成し た皮膜と比較した。

3-1-1 カタサ

各試験片についてヒッカキカタサを測定した結果, 亜 鉛を添加した浴中で生成した皮膜がもっとも硬く，硫酸 陽極酸化膜に比べてやや劣るが，水酸化ナトリウム単独 浴中にて生成した皮膜よりも硬いことを認め，ついで， バナジンが効果のあることを認めた。また，封孔処理に よる影響については，沸騰水封孔よりも常温封孔のほう が，皮膜を硬くすることを認めた。

\section{3-1-2 耐アルカリ性}

垔鉛添加浴中で得られた皮膜がもっとも耐アルカリ性 にすぐれ，とくに封孔処理により，耐アルカリ性を增大 することが認められた。たとえば，亜鉛添加浴中で得ら れた皮膜は沸騰水にて封孔した試片と同し膜厚 の硫酸 陽極酸化膜を，沸騰水封孔した試片と比較すると前者の $320 \mathrm{~s}$ に対して後者は30 sで（ただし, 硫酸陽極酸化膜 未封孔 $15 \mathrm{~s}$ ，亜鉛添加浴中で得られた皮膜，未封孔 $65 \mathrm{~s}$ )

第 2 表 耐酸性 (硫酸*) 試験結果

\begin{tabular}{|c|c|c|c|}
\hline 試験片種類 & 未封 孔 & 沸騰水封孔 & 常温封孔 \\
\hline $\begin{array}{l}\text { 硫 酸 } \\
\text { 陽酸化皮膜 }\end{array}$ & $93.2 \%$ & $27.0 \%$ & $63.9 \%$ \\
\hline $\begin{array}{l}\text { アルカリ性 } \\
\text { 陽極酸化皮膜 } \\
\text { (Cd添加浴) }\end{array}$ & $63.6 \%$ & $5.9 \%$ & $20.6 \%$ \\
\hline $\begin{array}{l}\text { アルカリ性 } \\
\text { 陽極酸化皮膜 } \\
(\mathrm{Zn} \text { 添加浴) }\end{array}$ & $34.1 \%$ & $2.7 \%$ & 7. $2 \%$ \\
\hline
\end{tabular}

* 硫酸： $10 \%, 50^{\circ} \mathrm{C}$

試料膜厚 : $7 \mu$

漫セキ時間：未封孔 $15 \mathrm{~min}$, 封孔試片 $60 \mathrm{~min}$
あった。また，他に，ビスマス，カドミウム, バナジン およびモリブテンなどの効果がよく，沸騰水封孔では， 硫酸陽極化膜および水酸化ナトリウム単独浴中で得られ た皮膜よりる耐アルカリ性にすぐれていることを認めた が，常温封孔処理を行なった試片では，水酸化ナトリウ ム単独浴中で生成した皮膜がもっとも耐アルカリ性大 で，ついで亜鉛添加浴中で得られた皮膜であったが，そ れぞれいずれの場合も硫酸陽極酸化膜よりも耐アルカリ 性にすぐれた皮膜を生成した。

3-1-3 耐酸性

3-1-3-1 皮膜八ク離液による結果

リン酸一クロム酸による皮膜八ク離液に浸セキし，完 全に皮膜が溶解した時間を測定し，第 1 表に示した。亜 鉛添加中で得られた皮膜は，70 s 間浸セキしても完全に 溶解せず，もっとも耐酸性にすぐれた皮膜を得た。

以上, ヒッカキカタサ, 耐アルカリ性および耐酸性 （皮膜ハク離液）の結果を第1表にまとめて示した。

3-1-3-2 硫酸による結果

$50^{\circ} \mathrm{C}$ の $10 \%$ 硫酸に膜厚 $7 \pm 1 \mu$ の試験片を, 未封孔 の試験片については15min, 封孔処理した試験片につい ては $60 \mathrm{~min}$ 間漫セキし, 皮膜の溶解量をパーセントに て求めた。皮膜が完全に溶解した場合, 素地も続いて溶 解されるので，皮膜の残存をテスターにて，それぞれの 試験片につき確認しながら浸セキした。

計算法は，次式により行なった。

$$
\text { 皮膜溶解量 }(\%)=\frac{\text { 皮膜溶解量 }(\mathbf{g})}{\text { 量 }(\mathbf{g})} \times 100
$$

打の扣のの試験片について，硫酸に浸セキする前後の重 量を測定し, その後, 皮膜八ク離液に浸セキして皮膜を 完全に溶解して，乾燥後重量を測定した。上式に示した 皮膜重量は, 試験液の $10 \%$ 硫酸に浸セキする前の重量 より，皮膜を皮膜ハク離液にて完全に溶解させた後の試 験片の重量を差し引いた值であり，また，皮膜溶解量 $(\mathrm{g})$ は，硫酸に浸セキした前後の重量の差を用いた。この実 験では，カドミウム添加浴および亜鉛添加浴中で生成し た皮膜と硫酸陽極酸化膜とを比較し，第 2 表に示した。

\section{3-1-4 電流一電圧曲線}

水酸化ナトリウム単独浴および带鉛添加浴中では, 10 〜 $15 \mathrm{~V}$ まで電流值は急激に上昇したが, 以後徐々に上昇 した。しかし，水酸化ナトリウムに酒石酸を添加した浴 拉よびさらにカドミウムを添加した浴では, 約 $10 \mathrm{Vまで}$ 前者同様に電流值は急上昇したが，以後電圧の上昇に従 い低下した。すなわち，酒石酸塩の添加した浴と涯加し ない浴とでは，異なった曲線を示した（第1图)。

\section{3-1-5 電流拉よび電圧と電解時間との関係}

カドミウムおよび亜鉛を添加したそれぞれの浴を用い て，電流值および電圧の経時変化を $30 \mathrm{~min}$ まで測定し 


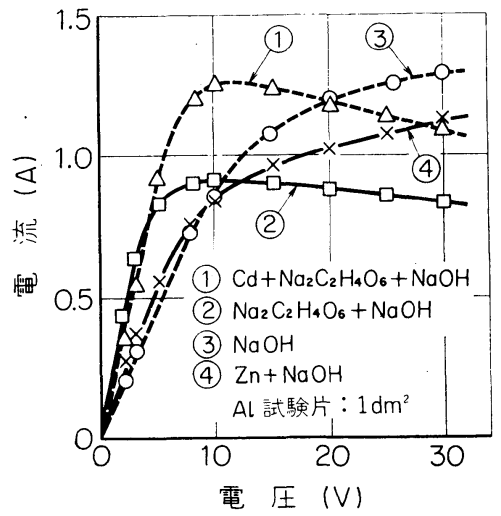

第 1 图 電流一電圧曲線

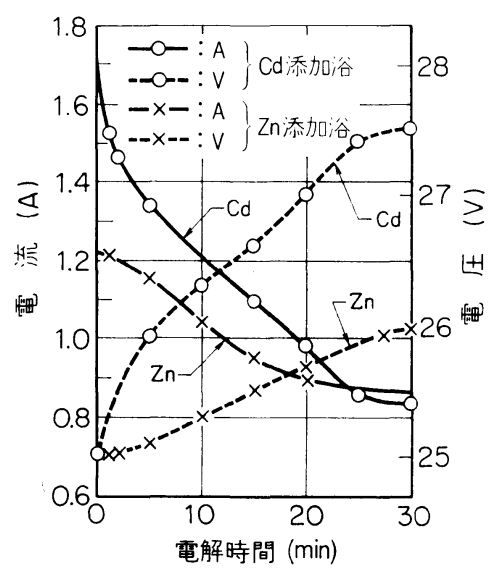

第2図電流值および電圧と電解時間との関係
た。

結果を第 2 図に示したが，約 $20 \mathrm{~min}$ まで電流值は低 下し，以後ほとんど一定值を示した。

\section{3-2 二重電解皮膜}

二重電解皮膜の生成法として，アルカリ性浴中で陽極 酸化注 ${ }^{1}$ ) 後, 硫酸浴中て陽極酸化注 ${ }^{2}$ )する方法(以上A法 と略す）と，逆に，硫酸浴中で陽極酸化注 ${ }^{1}$ 後, アルカ

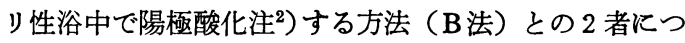
き検討した。

$\mathrm{A}$ 法および $\mathrm{B}$ 法ともに，第一段電解時の電流密度は， $1 \mathrm{~A} / \mathrm{dm}^{2}$ とし $30 \mathrm{~min}$ 間行ない, $7 \pm 1 \mu$ の皮膜を生成 させ二重皮膜生成用の試片とした。この場合, 試片は $0.3 \mathrm{dm}^{2}(3 \times 5 \times 0.03 \mathrm{~cm})$ とした。

\section{3-2-1 電流値と電解時間との関係}

アルカリ性電解皮膜を試験片としたA法は，第 3 図(1) 牤よび(2)に示したように，初期電流密度を低く設定した が，第3図(1)の場合，約 $10 \mathrm{~min} 飞 て 1 \mathrm{~A} / \mathrm{dm}^{2}$ 飞達し， 約 15〜20 min 後より徐々に電流值は低下した。このと きの膜厚を測定した結果, 眓中に示した 上らに30minで14 $1 \mu$ を得た。また，

第3 図(2)についても曲線は同じ傾向を示 し，各種試験用の試験片を作成するさい 飞は，電流值が $1 \mathrm{~A} / \mathrm{dm}^{2}$ になるよう約 $5 \mathrm{~min}$ 後より電圧を上昇させて調整し た。その結果, (1)の場合と同様に, 30 min の電解で $14 \pm 1 \mu$ の皮膜を得た。初期電

注1）A法， B 法ともに第一段電解と 以下略称する。

注2） A 法， B 法ともに第二段電解と 以下略称する。
流密度を低く設定したのは，電流密度を $1 \mathrm{~A} / \mathrm{dm}^{2}$ に設 定して, 最初より電解を行ならと, 電圧は約 $70 \mathrm{~V}$ 以上と なり皮膜が破壊されたためである。

上記方法では, 膜厚約 $7 \mu$ の増加を認めたが, 素材を 同じ浴中で, $1 \mathrm{~A} / \mathrm{dm}^{2} に て 30 \mathrm{~min}$ 間陽極酸化を行なら と, 約 $7 \mu$ の皮膜を得るので, 硫酸浴中で陽極酸化した さい, 試験片のアルカリ性電解皮膜が注とんど溶解され ていないものと思われる。

一方, B 法では A法の上うに, 電流密度を大にする と, $20 \mathrm{~min}$ 程度まではほぼ同じょらに膜厚は増加した が，電流値が安定しにくく，局部的に大電流が流れ，ヤ ケを生じ, 皮膜が破壊された。また，20min 以上の電解 では試験片の膜厚より減少し, 一度生成した皮膜が溶解 されることを認めた。

したがって，本実験では第3図（3）に示したように， 上記のような支障をさけるために, 低い電流密度にて第 二段電解を行なった。この結果では $30 \mathrm{~min}$ 間の電解に $\tau, 9 \mu$ の皮膜を得た。

第 3 表 二重電解皮膜（A法）の耐酸, 耐アルカリ性試験結果

\begin{tabular}{|c|c|c|c|}
\hline 試験液 & $\begin{array}{l}\mathrm{Zn} \text { 添加浴 } \\
\rightarrow \mathrm{H}_{2} \mathrm{SO}_{4}\end{array}$ & $\begin{array}{l}\mathrm{Cd} \text { 添加浴 } \\
\rightarrow \mathrm{H}_{2} \mathrm{SO}_{4}\end{array}$ & $\mathrm{H}_{2} \mathrm{SO}_{4}$ \\
\hline $\begin{array}{l}10 \% \mathrm{H}_{2} \mathrm{SO}_{4} \\
\left(50^{\circ} \mathrm{C}, 60 \mathrm{~min}\right)\end{array}$ & $-2.0 \mu$ & $-3.0 \mu$ & $-7.5 \mu$ \\
\hline $\begin{array}{c}\mathrm{H}_{3} \mathrm{PO}_{4}-\mathrm{CrO}_{3} \\
\left(95^{\circ} \mathrm{C}, 1 \mathrm{~min}\right)\end{array}$ & $-1.5 \mu$ & $-1.5 \mu$ & $-4.5 \mu$ \\
\hline $\begin{array}{r}10 \% \mathrm{NaOH} \\
\left(30^{\circ} \mathrm{C}\right)\end{array}$ & 表面皮膜残 & $\begin{array}{c}5 \min :-2 \mu \\
8 " \vdots \equiv \\
11 "-4 \mu\end{array}$ & $\begin{array}{c}2.5 \mathrm{~min}: 1 \mu \\
5 \mathrm{~N}: \text { 完溶 }\end{array}$ \\
\hline
\end{tabular}

膜厚 $14 \pm 1 \mu, 30 \mathrm{~min}$ 間沸騰水封孔した試験片使用 （ただ，アルカリ性電解皮膜は $7 \pm 1 \mu$ の試片を使用） 


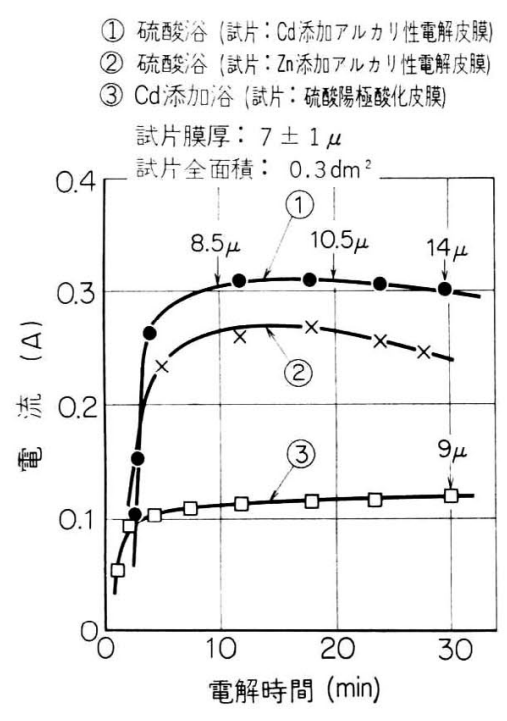

第3図 電流値と電解時間との関係

\section{3-2-2 A 法の耐酸および耐アルカリ性試験結果}

試片には，亜鉛およびカドミウム添加浴中で得られた 二者のアルカリ性電解皮膜を用い, 硫酸浴中でさらに陽 極酸化を行ない, $14 \mu$ の皮膜を生成させ, 第 3 表に示し た試験液に, それぞれの条件で浸セキし, 溶解減少した 皮膜厚サを, 同じ膜厚の硫酸陽極酸化膜と比較して示し た。この結果より, 硫酸陽極酸化膜に比べて二重電解皮 膜が耐酸性，耐アルカリ性にすぐれていることを認め た。（第 4 表）

表中，表面皮膜残と記したのは，「亜鉛添加浴 $\rightarrow$ 硫酸」 により得られた皮膜が，水酸化ナトリウムにより，表面 皮膜を残し，下層より溶解されたため皮膜が浮いた状態 そなって残存したことを意味する。

3-2-3 A法のアルカリ滴下試験とヒッカキカタサ

アルカリ性電解皮膜として，水酸化ナトリウム単独 浴, 亜鉛添加浴, カドミウム添加浴およびビスマス添加

第 4 表 二重電解皮膜（A法）の耐アルカリ性と ヒッカキカタサ試験結果

\begin{tabular}{c|c|c|c}
\hline \hline $\begin{array}{c}\text { アルカリ性 } \\
\text { 電解皮膜 } \\
(\mu)\end{array}$ & \multicolumn{3}{|c}{ 硫酸陽極酸化 (30 min) } \\
\cline { 2 - 5 } & 膜厚 $(\mu)$ & $\begin{array}{c}\text { ヒッカキ } \\
\text { カ タ }\end{array}$ & 耐アルカリ性 \\
\hline $\mathrm{NaOH}$ & 14 & 18.5 & $25(\mathrm{~s})$ \\
\hline $\mathrm{Zn}$ 添加浴 7 & 14 & 27.7 & - * \\
\hline $\mathrm{Cd}$ 添加浴 7 & 14 & 25.3 & 40 " \\
\hline $\mathrm{Bi}$ 添加浴 7 & 14 & 19.8 & 25 " \\
\hline \hline
\end{tabular}

試験片は未封孔

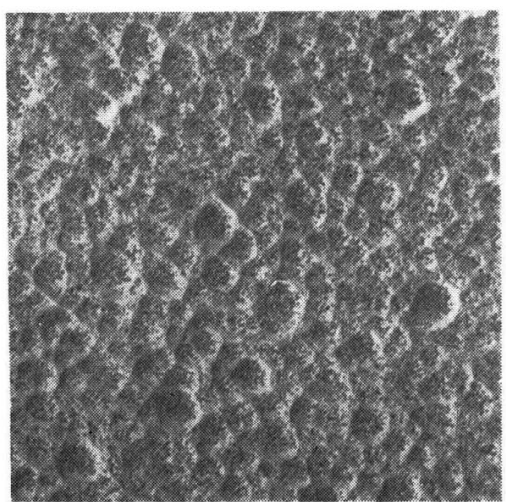

$$
\underset{\mathrm{Zn}}{\mathrm{NaOH}} \text { 浴 } \longrightarrow \mathrm{H}_{2} \mathrm{SO}_{4} \text { 浴 }
$$

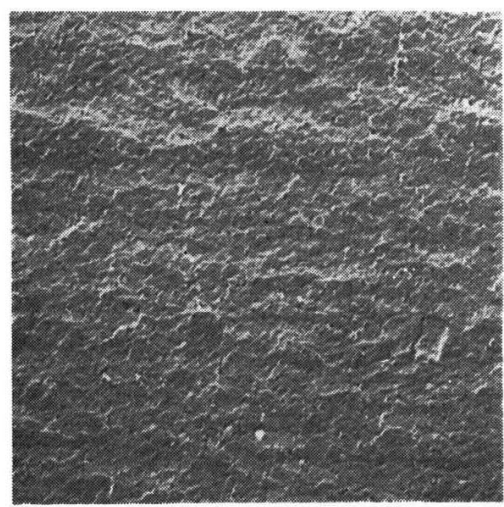

$\underset{\mathrm{Zn}}{\mathrm{NaOH}}$ 浴

写真 1 電子顕微鏡写真 $(\times 4000)$

浴中で得られた皮膜を用い，硫酸浴中で陽極酸化を行な い14 $\mu$ の皮膜を生成させて試験を行なった(第 5 表)。

表中*印は, 3-2-2で述べたように, 皮膜が浮き出し, 正確な測定が不可能なため数值を省略したが，ほぼ40 s 以上であると思われる。ゆえに，第一段電解にてアルカ リ浴中に亜鉛を添加することにより，カタサ，耐アルカ

第 5 表 二重電解皮膜（B法）の耐酸, 耐アルカリ試験結果

\begin{tabular}{|c|c|c|}
\hline $\begin{array}{l}\text { 皮膜生成法 } \\
\text { 試験法 }\end{array}$ & $\begin{array}{l}\mathrm{H}_{2} \mathrm{SO}_{4} \rightarrow \\
\mathrm{Cd} \text { 添加浴 }\end{array}$ & $\mathrm{H}_{2} \mathrm{SO}_{4}$ \\
\hline $\begin{array}{l}10 \% \mathrm{H}_{2} \mathrm{SO}_{4} \\
\left(50^{\circ} \mathrm{C}, 60 \mathrm{~min}\right)\end{array}$ & $-6.5 \mu$ & $-4.0 \mu$ \\
\hline $\begin{array}{c}\mathrm{H}_{3} \mathrm{PO}_{4}-\mathrm{CrO}_{3} \\
\left(95^{\circ} \mathrm{C}, 1 \mathrm{~min}\right)\end{array}$ & $-7.0 \mu$ & $-3.0 \mu$ \\
\hline $\begin{array}{r}10 \% \mathrm{NaOH} \\
\left(30^{\circ} \mathrm{C}\right)\end{array}$ & $1 \mathrm{~min}$ : 完溶 & $\begin{array}{l}1 \mathrm{~min}:-1.5 \mu \\
2 \geqslant: \text { 完溶 }\end{array}$ \\
\hline
\end{tabular}

膜厚 $9 \pm 1 \mu, 30 \mathrm{~min}$ 間沸騰水封孔した試片使用 
リ性とともに増大させることができた。

3-2-4 B法の耐酸执よび耐アルカリ性試験結果

3-2-2 と同じ方法にて 行なったが，硫酸陽極酸化膜に 比べて溶解量も多く，第二段電解であるアルカリ性電解 皮膜の膜厚が少ないことも考えられるが， B法では二重 電解皮膜として，A法に比べ，耐酸性および耐アルカリ 性に劣ることを認めた(写交1)。

\section{4. 考察}

\section{4-1 金属塩添加による効果}

アルカリ性に可溶性の金属塩として 8 種選択して用い たが，メタアルミン酸ナトリウムの添加した浴中で生成 した皮膜と水酸化ナトリウム単独浴中で生成した皮膜と を，ヒッカキカタサ，耐アルカリ性および耐酸性につい て比較すると, カタサについてはほとんど差異は認めら れないが，耐アルカリ性执よび耐酸性については，前者 の皮膜がすぐれていた。ゆえに，水酸化ナトリウムが増 大すると，さらに耐アルカリ性技よび耐酸性にすぐれた 皮膜を生成すると考えられる。

また，亜鉛添加浴中で生成した皮膜は硫酸陽極 酸 化 膜，アルカリ単独浴中での皮膜および他の金属塩を添加 した皮膜などと比較して，もっとも耐アルカリ性，耐酸 性にすぐれていることを認めたが，亜鉛と化学的性質の 類似したカドミウムの効果はあまり無く,さらに, ベリ リウムの効果については, 8 種の金属塩の中もっとも坌 ることを認めた。

亜鉛添加浴では，酒石酸ナトリウムを添加していない が, カドミウム添加浴へは，カドミウムの沈殿防止斉と して酒石酸ナトリウムを添加したが，第1図の結果か ら, 両者ともに約 $10 \mathrm{~V}$ 付近まで急速に電流値が上昇し, 前者では, 以後電圧の上昇とともに電流値も徐々に上昇 したが, 後者では, 電流值が低下した。ゆえに, アルカ リ浴中に酒石酸ナトリウムを添加した浴および水酸化ナ トリウム単独浴について同様に電流一電圧曲線を求めた が，水酸化ナトリウム単独浴中で得た曲線は，亜鉛添加 浴で得た曲線に，酒石酸ナトリウムを添加した浴中で得 た曲線は，カドミウム添加浴中で得た曲線にそれぞれ類 似した。すなわち, 酒石酸ナトリウムの存在する浴で は, 約 $10 \mathrm{~V}$ 以上で電流值が低下することより急速に皮膜 の生成することが考えられ，一方，酒石酸ナトリウムを 添加しない浴中では，皮膜生成速度が緩慢であると考兄 られる。また，それぞれの曲線が屈曲する電圧以上で浴 中に存在するイオン種〔亜鉛涯加浴では $\mathrm{ZnO}_{2}{ }^{2-}$, カド ミウム添加浴では $\mathrm{Cd}\left(\mathrm{C}_{4} \mathrm{H}_{4} \mathrm{O}_{6}\right)_{2}{ }^{2-}$ とも考えられる]が電 解を受け，それぞれの金属が酸化物または水酸化物とし て皮膜を形成するものと考えられる。第 2 図に，電流一 時間曲線を示したが，亜鉛添加浴では電解初期において
急激な電流值の降下は見られないが，カドミウム添加浴 では，短時間にて急速に低下した。このことより，皮膜 の生成が，カドミウム添加浴中にて電解初期に急速に行 なわれるものと考えられる。

\section{4-2 二臬党解皮膜}

アルカリ性浴中で陽極酸化後, 硫酸浴中にて陽極酸化 を行なう A 法では, 硫酸浴中での第二段電解, $10 \mathrm{~min}$ に て $1.5 \mu, 20 \mathrm{~min}$ にて $3.5 \mu, 30 \mathrm{~min}$ にて $7 \mu$ の膜厚増 加を認めた（第3図(1)）。ゆえに，第一段電解により得 られた皮膜は，ほとんと硫酸浴中で溶解されていないと 考えられる。一方，B法ではA法と同様に第二段電解に て $1 \mathrm{~A} / \mathrm{dm}^{2}, 30 \mathrm{~min}$ 間陽極酸化を行ならと皮膜の溶解 が大きく試験片の膜厚 $7 \mu$ よりも減少することを認めた ので，第 3 図(3)に示したように低電流密度にて，電解を 行なった結果, 約 $9 \mu$ の皮膜（ $2 \mu$ の膜厚増加）を生成 した。

皮膜の生成状態については, 第 3 表の「 $\mathrm{Zn}$ 添加浴 $\rightarrow$ $\mathrm{H}_{2} \mathrm{SO}_{4} 」$ 皮膜のアルカリ試験結果より，表面皮膜が残り 試験片素地から浮さ出していることを認めたが，第一段 電解にて生成した皮膜の下層に第二段電解の皮膜が生長 生成するものと考られる。この理由として, アルカリ性 電解皮膜は，耐アルカリ性にすぐれているために，耐ア ルカリ性に劣る硫酸電解皮膜がさきに溶解すると思われ るためである。「カドミウム添加浴一硫酸」試片では, アルカリ性電解皮膜であるカドミウム添加浴中で得られ た皮膜の耐アルカリ性は，亜鉛添加浴での皮膜に比べて 劣るため，表面皮膜が残ることなく溶解したものと考え られる。第 3 表にて硫酸皮膜と比較したが，皮膜の水酸 化ナトリウムに対する溶解速度は, 硫酸陽極酸化膜が $5 \mathrm{~min} に て$ 完全に溶解したのに対して，上記試片では， $5 \min に \tau 2 \mu$ 溶解したのみであった。したがって， A 法にて生成した二重皮膜は, アルカリに対する溶解時間 の面より考察すると，硫酸電解皮膜自体も耐アルカリ性 にすぐれた皮膜として生成しているのではないかと考え られる。

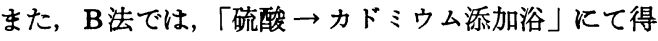
られた試験片のみについて硫酸陽極酸化膜と比較した が, 耐酸性および耐アルカリ性の両者ともに, 硫酸陽極 酸化膜よりも劣ることを認めたが，第二段電解にて厚い 皮膜を生成しなかったことおよびアルカリ性浴中で硫酸 陽極酸化膜の皮膜構造が一部破壊されたことなどが理由 と考えられる。

\section{5. 結 論}

\section{5-1 金属塩添加による効果}

1） 8 種類の金属塩を選択し用いたが，各種試験結果 は, 亜鉛添加の効果がもっともすぐれ，ベリリウムの効 
果が少ることを認めた。

2）硫酸陽極酸化膜と種々の金属塩を添加したアルカ リ性浴中で得られた皮膜とを，ヒッカキカタサ，耐アル カリ性拉よび耐酸性について比較した結果, アルカリ皮 膜は，ヒッカキカタサは劣るが，耐酸性および耐アルカ リ性についてはすぐれていることを認めた。とくに，封 孔処理した試片について顕著であった。

3）水酸化ナトリウム単独浴で生成した皮膜と比較し た結果，未封孔の試片では，ヒッカキカタサおよび耐ア ルカリ性について同じ程度のものが $2 ， 3$ あった（アル ミニウムおよびモリブデン添加浴……カタサ, ビスマス 添加浴……耐アルカリ性）が，他の試片については良い 結果を得た。耐酸性については，亜鉛の添加がとくに効 果があり，他の皮膜はほぼ同じ結果を得た。

沸騰水封孔した試片では, 耐アルカリ性でタングステ ンおよびベリリウム添加浴での皮膜, 耐酸性でモリブデ ン添加浴での皮膜が劣った。しかし，他の皮膜について は良い結果を得，ヒッカキカタサについてる，すぐれた 結果を得た。

4) 加水分解防止のために酒石酸ナトリウムを添加し た浴では，電解初期に打ける皮膜生成速度が大なること を認めた。また，電流一電圧曲線の結果より，10V以上 の電圧で電解することが適していると考兄られる。

\section{5-2 二亘解皮膜}

1） A法では，第二段電解により第一段電解の皮膜が
ほとんど溶解されることなく、アルミニウム素地に, 硫 酸浴中で得られる膜厚とほ注同じ厚サの皮膜增加を認め た。しかし，B法では，アルカリ性浴中で，第一段電解 の硫酸皮膜が溶解され，厚い皮膜が溶解せず， $1 / 3 \mathrm{~A} / \mathrm{dm}^{2}$ の電流密度で第二段電解を行なったが，30 min で約 $2 \mu$ の皮膜増加があり，電流密度の高い場合 (約 $1 \mathrm{~A} / \mathrm{dm}^{2}$ ) の $10 \mathrm{~min}$ 間電解による膜厚に相当したが，長時間 (30 $\min$ 以上）電解を行なうと膜厚は減少した。

2 ）耐酸性拉よび耐アルカリ性試験の結果, 両者とも に硫酸陽極酸化膜単独の場合よりもすぐれ，カタサにつ いてもすぐれた結果を得た。

3）金属塩添加の効果として，二重電解皮膜について も，悪鉛添加浴中で第一段電解を行なった場合，ヒッカ キカタサ，耐酸性および耐アルカリ性にすぐれた皮膜の 生成することを認めた。

4）A法にて生成した二重電解皮膜は，アルカリ性皮 膜の耐アルカリ性にすぐれている長所および硫酸陽極酸 化皮膜のカタサ大なる長所の両者を兼坟備えていると思 われる。

(1971-5-22 受理)

（昭和45年 5 月，本協会第 41 回学術講演大会にて発表）

\section{文献}

1）吉村，実務表面技術，No.12，16（1970）

2) 中山, アルミニウムの表面処理, p. 303 (1969, 日 刊工業新聞社)

\section{金属表面技術関連規格集（増補改討版）}

本協会では昭和41年にく金属表面技衔関臬規格集（J I S 集)）を刊行いたしましたが，発行と同時に大きな 反響を呼びました。

今般新しくく増補改訂版〉を発行いたすことになり，初版に揭載できなかったものや改訂になったものなどの 增補改訂をいたしました。印刷部数に制限がありますのでお早目にお申込み下さい。
形式
B 5 版
ページ数 約 900 ページ
集録件数 77 件

内 容 金属記号の表わし方, 材料記号一覧, 用語 4 件, 研摩 18件, 電気メッキ 15件, 溶融メッキ・溶射 11 件, 陽極酸化 2 件, 硬化 3 件, 塗料・塗装 4 件, ライニング・コーチング 5件，試験法および測定法 18件， その他参考規格 30件，

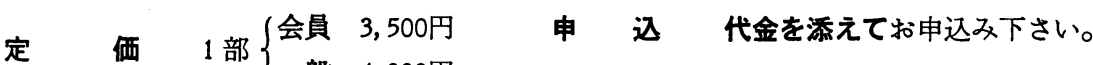

社団法人 金 属 表 面 技 術 協 会 